\title{
PENINGKATAN KEMAMPUAN MENGIDENTIFIKASI INFORMASI DALAM TEKS DISKRIPTIF MELALUI PENDEKATAN KOOPERATIF TIPE JIGSAW PADA SISWA KELAS VII 6 SMP NEGERI 1 NGANJUK TAHUN PELAJARAN 2018/2019
}

\author{
Rr. ERY KUSUMA INDRYATI \\ SMPN 1 NGANJUK, JAWA TIMUR \\ E-mail : erykusumaa@gmail
}

\begin{abstract}
ABSTRAK
Beberapa penyebab rendahnya pretasi belajar siswa SMP Negeri 1 Nganjuk, diantaranya sebagai berikut: (1) Kurangnya perhatian guru pada pengajaran menulis di kelas, (2) Strategi mengajar guru kurang bervariasi, (3) Penguasaan kosa kata dan tata bahasa siswa yang rendah.,dan (4) Siswa cenderung mencontoh karya temannya atau karya terdahulu di bukubuku pelengkap pelajaran lainnya. Rumusan masalah dalam penelitian ini adalah (1) Apakah penerapan Pendekatan Kooperatif Tipe Jigsaw dalam pembelajaran pelajaran Bahasa Indonesia, dapat mengidentifikasi Informasi dalam Teks Diskriptif siswa kelas VII 6 SMP Negeri 1 Nganjuk tahun pelajaran 2018/2019?, dan (2) Bagaimanakah mengidentifikasi Informasi Dalam Teks Diskriptif siswa kelas VII 6 SMP Negeri 1 Nganjuk tahun pelajaran 2018/2019 setelah penerapan Pendekatan Kooperatif Tipe Jigsaw? Analisis data dihitung dengan mean (rata-rata hitung) dan persentase (\%) . Keterangan nilai kuantitatif rata-rata hitung dengan angka dalam bentuk skor 0 - 100 (bilangan bulat) sedangkan secara kualitatif keterangan nilai dengan huruf, sebagai berikut: (1) $91-100 \%=\mathrm{A}$ (amat baik) - (tuntas); (2) $75-90 \%=\mathrm{B}$ (baik) - (tuntas); (3) $70-74 \%=\mathrm{C}$ (cukup) - (tidak tuntas); (4) $40-69 \%=\mathrm{D}$ (kurang) - (tidak tuntas); dan (5) $<40 \%=\mathrm{KS}$ (kurang sekali) - (tidak tuntas) Berdasarkan hasil penelitian disimpulkan bahwa: (1) Melalui penerapan Pendekatan Kooperatif Tipe Jigsaw, maka kemampuan mengidentifikasi Informasi dalam Teks Diskriptif pada Siswa Kelas VII 6 SMP Negeri 1 Nganjuk Tahun Pelajaran 2018/2019 dapat meningkat dari sebelumnya; dan (2) Peningkatan kemampuan mengidentifikasi Informasi dalam Teks Diskriptif pada Siswa Kelas VII 6 SMP Negeri 1 Nganjuk Tahun Pelajaran 2018/2019 adalah sebagai berikut: (1) Nilai rata-rata meningkat 12,66 (dari 71,56/hasil prasiklus menjadi 84,22 pada siklus II). (b) Jumlah siswa berhasil meningkat 18 siswa (dari 13/ prasiklus menjadi 31 siswa pada siklus II). (c) Persentase keberhasilan meningkat 56,26\% (dari 40,63\%/ prasiklus menjadi $96,88 \%$ pada siklus II)
\end{abstract}

Kata Kunci : teks deskriptif, kooperatif, Jigsaw

\section{PENDAHULUAN}

Pembelajaran Bahasa Indonesia di sekolah mencakup empat keterampilan bahasa yaitu menyimak, berbicara, menulis, dan membaca. Setiap keterampilan tersebut erat hubungannya dengan keterampilan lainnya. Dalam memperoleh keterampilan berbahasa, biasanya melalui suatu hubungan urutan yang teratur. Mula-mula, pada masa kecil, anak belajar menyimak, lalu berbicara, kemudian setelah sekolah anak akan belajar membaca dan menulis yang tetap dipelajari ke jenjang yang lebih tinggi. Hal ini disebabkan keempat keterampilan tersebut pada dasarnya merupakan suatu kesatuan atau catur tunggal.

Perbaikan metode mengajar perlu digunakan dengan tujuan merangsang dan mendorong minat dan motivasi belajar siswa. Perbaikan strategi mengajar ini akan mempunyai dampak dan pengaruh positif terhadap pencapaian prestasi belajar siswa. Asumsinya adalah jika satu atau dua metode yang digunakan guru dalam proses belajar mengajar ternyata hasilnya kurang memuaskan, maka guru dapat menggunakan strategi lainnya yang paling dianggap tepat dan sesuai dengan bahan atau materi pelajaran dan sesuai dengan pengetahuan, kemampuan serta perkembangan siswa, alat dan media belajar yang dimiliki sekolah. Tujuan akhir dari perbaikan strategi ini adalah pencapaian prestasi belajar 
yang maksimal sesuai dengan tujuan mata pelajaran yang telah ditetapkan dalam kurikulum yang berlaku.

Peningkatan mutu pembelajaran menulis di Sekolah Menengah Pertama melalui pengembangan berfikir kritis, logis, dan kreatif sangat berkaitan dengan upaya melibatkan siswa aktif dalam pembelajaran menulis deskripsi, khususnya menulis hasil mengidentifikasi teks. Seperti diketahui, seringkali kita merasa prihatin bahwa penguasaan ketrampilan menulis siswa lemah. Keterampilan menulis dianggap sulit Berdasarkan data awal sebelum penelitian ini dilakukan, rata-rata mengidentifikasi Informasi dalam Teks Diskriptif siswa kelas VII 6 SMP Negeri 1 Nganjuk, tahun pelajaran 2018/2019 hanya mencapai 70,00. Nilai ini masih di bawah rata-rata standar ketuntasan minimal yang ditetapkan (minimal 75,00). Beberapa penyebab rendahnya pretasi belajar siswa SMP Negeri 1 Nganjuk , diantaranya sebagai berikut: (1) Kurangnya perhatian guru pada pengajaran menulis di kelas, (2) Strategi mengajar guru kurang bervariasi, (3) Penguasaan kosa kata dan tata bahasa siswa yang rendah.,dan (4) Siswa cenderung mencontoh karya temannya atau karya terdahulu di buku-buku pelengkap pelajaran lainnya.

Untuk menghindari permasalahan di atas, dan agar permasalahan tersebut dapat teratasi dengan baik, maka terdapat berbagai cara yang dapat dilakukan oleh guru agar siswa mampu meningkatkan kemampuannya dalam menyerap dan menerima materi pelajaran, serta mengupayakan pembelajaran menjadi bermakna baik bagi siswa maupun guru. Salah satu cara yang dapat dilakukan guru adalah melakukan inovasi pembelajaran dengan menerapkan pendekatan kooperatif tipe Jigsaw. Pendekatan kooperatif sebagai cara belajar bersama dalam mencapai tujuan yang dikehendaki, dalam hal iniprestasi belajar siswa. Pendekatan kooperatif dengan tipe Jigsaw ini merupakan cara penyampaian materi pembelajaran dengan teknik diskusi model Jigsaw. (Lie: 2002:112). Dalam metode Jigsaw ini siswa dihadapkan pada kerja tim ahli dalam setiap kelompok. Siswa dari tim berbeda dengan materi yang sama bertemu dalam suatu "kelompok ahli)

Diharapkan dengan diterapkannya Pendekatan Kooperatif Tipe Jigsaw ini siswa mampu meningkatkan prestasi belajarnya dalam upaya mengidentifikasi informasi dalam Teks Diskriptif yang disampaikan oleh guru. Di samping itu aktivitas siswa menjadi semakin meningkat. Sesuai dengan judul penelitian dan aspek-aspek yang diobservasi dalam penelitian, maka masalah PTK ini dapat dirumuskan berikut : (1) Apakah penerapan Pendekatan Kooperatif Tipe Jigsaw dalam pembelajaran pelajaran Bahasa Indonesia, dapat meningkatkan kemampuan mengidentifikasi informasi dalam teks diskriptif siswa kelas VII 6 SMP Negeri 1 Nganjuk tahun pelajaran 2018/2019?, dan (2) Bagaimanakah peningkatan kemampuan mengidentifikasi Informasi dalam Teks Diskriptif siswa kelas VII 6 SMP Negeri 1 Nganjuk tahun pelajaran 2018/2019 seletah penerapan Pendekatan Kooperatif Tipe Jigsaw?

\section{METODE PENELITIAN}

Penelitian ini dilaksanakan di SMP Negeri 1 Berbek Kabupaten Nganjuk, dengan subjek penelitian siswa kelas kelas VII 6 SMP Negeri 1 Nganjuk Kabupaten Nganjuk yang berjumlah 32 siswa. Objek penelitiannya adalah mengidentifikasi informasi dalam teks deskriptif.

Indikator kinerja merupakan indikator penetapan keberhasilan atau penetapan ketuntasan pelaksanaan penelitian tindakan kelas. Adapun indikator kinerja dalam penelitian ini dapat dijelaskan berikut: (1) Semakin meningkatnya nilai rata-rata kelas, minimal mencapai nilai 70 (KKM pelajaran Bahasa Indonesia) kategori baik; (2) Semakin meningkatnya nilai persentase ketuntasan hasil belajar yang dicapai siswa, minimal mencapai nilai 75\% (KKM pelajaran Bahasa Indonesia) kategori baik; (3) Semakin meningkatnya aktivitas siswa dalam pembelajaran, minimal mencapai nilai $50 \%$ siswa aktif dalam diskusi; (4) Semakin meningkatnya aktivitas guru dalam kegiatan pembelajaran, minimal mencapai nilai 3.5 kategori baik. 
Analisis data dihitung dengan mean (rata-rata hitung) dan persentase (\%). Keterangan nilai kuantitatif rata-rata hitung dengan angka dalam bentuk skor $0-100$ (bilangan bulat) sedangkan secara kualitatif keterangan nilai dengan huruf, sebagai berikut: (1) $91-100 \%=\mathrm{A}$ (amat baik) - (tuntas); (2) $75-90 \%=\mathrm{B}$ (baik) - (tuntas); (3) $70-74 \%=\mathrm{C}$ (cukup) - (tidak tuntas); (4) $40-69 \%=\mathrm{D}$ (kurang) - (tidak tuntas); dan $(5)<40 \%=\mathrm{KS}$ (kurang sekali) (tidak tuntas)

\section{HASIL PENELITIAN DAN PEMBAHASAN}

\section{Siklus I}

Hasil kegiatan pada tahap pelaksanaan ini berupa jawaban tes akhir siklus I dari siswa yang dikoreksi bersama pengamat. Setelah diadakan koreksi, maka hasil belajar siswa terhadap pembelajaran Bahasa Indonesia dengan materi pokok Mengidentifikasi Informasi Dalam Teks Diskriptif adalah sebagai berikut:

Tabel 1: Hasil Tes Akhir Siklus I

\begin{tabular}{|r|l|c|}
\hline \multicolumn{1}{|l|}{ NO } & \multicolumn{1}{|c|}{ ASPEK } & KET. \\
\hline 1 & Rata-rata kelas & 77,97 \\
\hline 2 & Yang Berhasil & 28 \\
\hline 3 & Persentase Keberhasilan & $87,50 \%$ \\
\hline
\end{tabular}

Sumber : Data Hasil Olahan Peneliti, 2018

Berdasarkan tabel di atas dapat dideskripsikan hasilnya sebagai berikut: (1) Hasil dari pelaksanaan tindakan pada siklus I ini berdasarkan tabel 1 di atas dapat dinyatakan bahwa ada peningkatan dalam mengidentifikasi informasi pada teks diskriptif siswa dari data awal berata-rata 71,56 menjadi 77,97 berarti ada kenaikan nilai sebesar 6,41; (2) Rincian hasil belajar siswa kelas VII 6 dalam mengidentifikasi informasi dalam teks diskriptif adalah sebagai berikut: (a) 5 siswa memperoleh nilai 90 (antara 75-90) B (tuntas); (b) 9 siswa memperoleh nilai 85 (antara 75-90) B (tuntas); (c) 8 siswa memperoleh nilai 80 (antara 75-90) B (tuntas); (d) 5 siswa memperoleh nilai 75 (antara 75-90) B (tuntas); (e) 3 siswa memperoleh nilai 70 (antara 60-74) C (tidak tuntas); (f) 2 siswa memperoleh nilai 65 (antara 60-74) C (tidak tuntas)

Berdasarkan jumlah siswa yang berhasil mendapatkan nilai di atas atau sama dengan 75 sebanyak 28 siswa, maka presentase keberhasilan siswa dari sejumlah 27 siswa mencapai $87,50 \%$. Perkembangan nilai siklus I dibanding dengan nilai kegiatan sebelumnya (prasiklus) menunjukkan peningkatan sebagai berikut : (1) Nilai rata-rata meningkat 46,87 nilai (dari 71,56 /hasil prasiklus menjadi 87,50); (2) Jumlah siswa berhasil meningkat 15 siswa (dari 13 /prasiklus menjadi 28 siswa); (3) Persentase keberhasilan meningkat 46,87\% (dari 71,56\%/ prasiklus menjadi $87,50 \%$ )

Berdasarkan hasil analisis data di atas dapat direfleksikan bahwa : "Penerapan Pendekatan Kooperatif Tipe Jigsaw yang dikembangkan pada siklus I belum berhasil, sehingga belum berpengaruh positif terhadap kemampuan siswa dalam mengidentifikasi informasi dalam Teks Diskriptif siswa kelas VII 6 SMP Negeri 1 Nganjuk” Dengan demikian perlu ada revisi sebagai langkah tindak lanjut pengembangan penerapan Pendekatan Kooperatif Tipe Jigsaw. Pada siklus I ini jumlah siswa berhasil baru mencapai 80,31\% (27 siswa). Sedangkan yang belum berhasil masih 19,69\% (5 siswa). Kelima siswa tersebut ketidakberhasilannya karena proses pemahaman terhadap materi pokok mengidentifikasi informasi dalam Teks Diskriptif. Oleh sebab itu pada siklus II perlu adanya penambahan/penajaman teori tentang cara mengidentifikasi informasi dalam Teks Diskriptif .

Di samping refleksi hasil belajar berupa prestasi belajar Bahasa Indonesia, pada kegiatan pembelajaran telah tampak berbagai keaktifan siswa sampai 31,6\% siswa (telah aktif) dalam dalam pelaksanaan PBM (diskusi kelompok) dengan baik. 


\section{Siklus II}

Setelah diadakan kegiatan berupa : (1) Pemantapan cara mengidentifikasi informasi dalam Teks Diskriptif; (2) Pemberian materi kosakata yang lebih banyak sehingga siswa mudah mengidentifikasi informasi dalam Teks Diskriptif ; (3) Pengoptimalan diskusi kelompok dengan penerapan Pendekatan Kooperatif Tipe Jigsaw, maka nilai siswa dalam mengidentifikasi informasi dalam Teks Diskriptif mengalami peningkatan. Hal ini dapat dilihat pada sajian tabel 4 berikut ini:

\section{Tabel 2: Hasil Tes Akhir Siklus II}

\begin{tabular}{|c|l|c|}
\hline NO & ASPEK & KET. \\
\hline 1 & Rata-rata kelas & 77,97 \\
\hline 2 & Yang Berhasil & 28 \\
\hline 3 & Persentase Keberhasilan & $87,50 \%$ \\
\hline
\end{tabular}

Sumber : Data Hasil Olahan Peneliti, 2018

Hasil dari pelaksanaan penelitian tindakan pada siklus II ini berdasarkan tabel 2 di atas dapat dinyatakan bahwa Ada peningkatan kemampuan siswa siswa dalam mengidentifikasi informasi dalam teks diskriptif dibanding siklus sebelumnya,yakni: (1) Nilai rata-rata meningkat 6,25 (dari 77.97 /hasil siklus I menjadi 84,22); (2) Jumlah siswa berhasil meningkat 3 siswa (dari 28/ siklus I menjadi 31 siswa); (3) Persentase keberhasilan meningkat 9,38\% (dari $87,50 \%$ / siklus I menjadi 96,88\%).

Rincian hasil belajar siswa kelas VII 6 dalam mengidentifikasi informasi dalam teks diskriptif adalah sebagai berikut: (a) 2 siswa memperoleh nilai 95 (antara 95-100) A (tuntas); (b) 7 siswa memperoleh nilai 90 (antara 75-90) B (tuntas); (c) 11 siswa memperoleh nilai 85 (antara 75-90) B (tuntas); (c) 9 siswa memperoleh nilai 80 (antara 75-90) B (tuntas); (d) 2 siswa memperoleh nilai 75 (antara 75-90) B (tuntas); dan (e) 1 siswa memperoleh nilai 70 (antara 60-74) C (tidak tuntas).

Selain hasil kegiatan berupa perstasi belajar (angka-angka), terdapat hasil pengamatan dari pengamat berupa keaktifan diskusi siswa. Hasil pengamatan keaktifan siswa meningkat daripada keaktifan siswa pada siklus I. Hasil pengamatan pengamat dapat dilihat pada tabel berikut ini:

Tabel 3: Hasil keaktifan siswa selama KBM

\begin{tabular}{|c|l|c|c|c|c|}
\hline NO & \multicolumn{1}{|c|}{ ASPEK } & $\begin{array}{c}\text { JML } \\
\text { SISWA } \\
\text { Siklus I }\end{array}$ & $\begin{array}{c}\text { PERSEN } \\
\text { TASE } \\
\text { Siklus I }\end{array}$ & $\begin{array}{c}\text { JML } \\
\text { SISWA } \\
\text { Siklus } \\
\text { II }\end{array}$ & $\begin{array}{c}\text { PERSE } \\
\text { NTASE } \\
\text { Siklus } \\
\text { II }\end{array}$ \\
\hline 1 & Antusias siswa dalam PBM & 18 & $56 \%$ & 29 & $91 \%$ \\
2 & Siswa aktif menjawab & 20 & $62 \%$ & 30 & $94 \%$ \\
3 & Siswa aktif membantu teman & 23 & $72 \%$ & 32 & $100 \%$ \\
4 & Aktif mengerjakan tugas & 22 & $69 \%$ & 32 & $100 \%$ \\
5 & Siswa aktif mendengarkan & 21 & $66 \%$ & 32 & $100 \%$ \\
\hline & Rata-rata & & $65 \%$ & & $97 \%$ \\
\hline
\end{tabular}

Sumber: Olahan Pengamat, 2018

Berdasarkan hasil pengamatan pada siklus II , kualitas belajar melalui penerapan Pendekatan Kooperatif Tipe Jigsaw menunjukkan kenaikan persentase sebesar $32 \%$ dari data siklus I $65 \%$ menjadi $97 \%$ siswa telah bisa pembelajaran kelompok dengan baik.

Berdasarkan hasil analisis di atas dapat direfleksikan bahwa :

“ Penerapan Pendekatan Kooperatif Tipe Jigsaw yang dikembangkan pada siklus II sudah berhasil dengan baik, sehingga sudah sangat berpengaruh positif terhadap mengidentifikasi Informasi Dalam Teks Diskriptif pada siswa kelas VII 6 SMP Negeri 1 Nganjuk." Dengan demikian tidak perlu ada revisi lagi sebagai langkah tindak lanjut 
pengembangan penerapan Pendekatan Kooperatif Tipe Jigsaw. Pada siklus II ini jumlah siswa berhasil sudah mencapai 96,88\% (31 siswa). Dengan demikian berdasarkan persentase keberhasilan yang dikehendaki dalam hipotesis tindakan di atas, maka penelitian ini sudah dapat dinyatakan berhasil dan tidak perlu diteruskan ke siklus III.

\section{Pembahasan Seluruh Siklus}

Berdasarkan hasil perhitungan pada siklus I dan II di atas, pekembangan hasil belajar Bahasa Indonesia materi pokok mengidentifikasi informasi dalam teks diskriptif tersebut dapat dilihat pada tabel 4 berikut ini:

\section{Tabel 4: Perkembangan Hasil Belajar Bahasa Indonesia Mengidentifikasi Informasi Dalam Teks Diskriptif Siswa Kelas VII 6 SMP Negeri 1 Nganjuk}

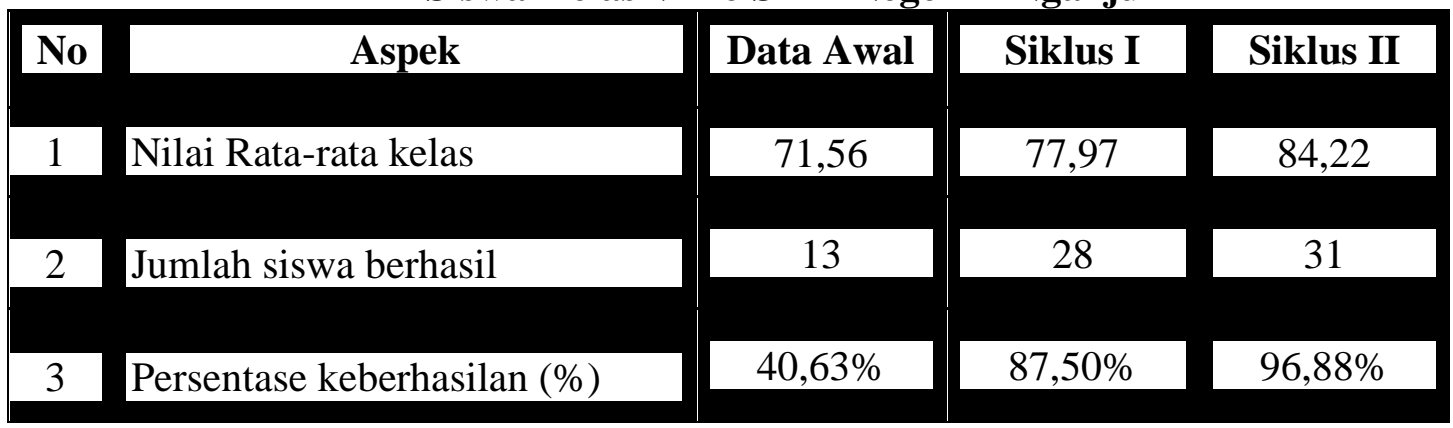

Sumber data : Olahan Peneliti, Hasil tes akhir siklus , 2018

Berdasarkan tabel 4 di atas dapat dideskripsikan bahwa : (1) Perkembangan nilai rata-rata kelas, jumlah siswa, dan persentase keberhasilan siswa dalam mengidentifikasi informasi dalam Teks Diskriptif pada setiap siklusnya selalu mengalami kenaikan; dan (2) Peningkatan yang terjadi dari data awal sampai siklus II dapat dirinci sebagai berikut : (a) Nilai rata-rata meningkat 12,66 (dari 71,56 /hasil prasiklus menjadi 84,22 pada siklus II); (b) Jumlah siswa berhasil meningkat 18 siswa (dari 13/ prasiklus menjadi 31 siswa pada siklus II); (c) Persentase keberhasilan meningkat 56,26\% (dari 40,63\%/ prasiklus menjadi 96,88\% pada siklus II).

Berdasarkan hasil perhitungan pada siklus I dan II di atas dapat direfleksikan bahwa : " Penerapan Pendekatan Kooperatif Tipe Jigsaw yang dikembangkan pada siklus I dan II sudah berhasil dengan baik, dan berpengaruh positif terhadap kemampuan siswa kelas VII 6 SMP Negeri 1 Nganjuk dalam mengidentifikasi informasi dalam Teks Diskriptif secara maksimal." Ternyata Pendekatan Kooperatif Tipe Jigsaw dapat mempengaruhi peningkatan mengidentifikasi informasi dalam Teks Diskriptif siswa kelas VII 6 SMP Negeri 1 Nganjuk yang ditunjukkan oleh perkembangan nilai tes akhir siklus I dan II pada materi pokok mengidentifikasi informasi dalam Teks Diskriptif kelas VII 6 SMP Negeri 1 Nganjuk yang pada siklus II ini sudah mencapai tingkatan kategori B (berhasil). Dengan demikian berdasarkan hipotesis tindakan yang ada maka penelitian ini dinyatakan telah berhasil, karena ternyata melalui penerapan Pendekatan Kooperatif Tipe Jigsaw, maka mengidentifikasi informasi dalam Teks Diskriptif siswa kelas SMP Negeri 1 Nganjuk Tahun Pelajaran 2018/2019 dapat meningkat.

\section{KESIMPULAN}

Berdasarkan rumusan masalah, deskripsi hasil analisis, dan refleksi hasil penelitian tersebut maka dapat disimpulkan bahwa : (1) Melalui penerapan Pendekatan Kooperatif Tipe Jigsaw, maka kemampuan mengidentifikasi informasi dalam Teks Diskriptif pada Siswa Kelas VII 6 SMP Negeri 1 Nganjuk Tahun Pelajaran 2018/2019 dapat meningkat dari sebelumnya; dan (2) Peningkatan mengidentifikasi Informasi Dalam Teks Diskriptif pada 
Siswa Kelas VII 6 SMP Negeri 1 Nganjuk Tahun Pelajaran 2018/2019 adalah sebagai berikut: (1) Nilai rata-rata meningkat 12,66 (dari 71,56/hasil prasiklus menjadi 84,22 pada siklus II). (b) Jumlah siswa berhasil meningkat 18 siswa (dari 13/ prasiklus menjadi 31 siswa pada siklus II). (c) Persentase keberhasilan meningkat 56,26\% (dari 40,63\%/ prasiklus menjadi $96,88 \%$ pada siklus II)

\section{DAFTAR PUSTAKA}

Adi, Tirto. 2007. Inovasi Pembelajaran, Media Pendidikan Surabaya: Kanwil P dan K Jawa Timur.

Arikunto, Suharsimi. 2012. Prosedur Penelitian Suatu Pendekatan Praktek. Jakarta: Rineka Cipta.

Hasibuan, JJ, Drs. Dkk. 2016. Proses Belajar Mengajar. Bandung : Remaja Rosdakarya.

Ibrahim, Muslimin dan Mohamad Nur. 2010. Pengajaran Berdasarkan Masalah. Surabaya : Pusat Sains dan Matematika Sekolah Program Pascasarjana Unesa.

Lie, Anita. 2012. Cooperative Learning. Jakarta : PT Grasindo Widiasarana.

Moh. Khoirul. 2011. Strategi Belajar Mengajar. Surabaya: Usaha Nasional.

Nur, Mohamad dan Prima Retno Wikandari. 2005. Pengajaran Berpusat Kepada Siswa dan Pendekatan Konstruktivis dalam Pengujaran. Surabaya : Pusat Sains dan Matematika sekolah.

Sunarto,. 2016. Bahasa Indonesia untuk Kelas VII SMP/MTs. Nganjuk:Tim MGMP. 